$\begin{array}{rr}\text { JURNAL } & \\ \text { FIT(1)PATOLOGI } & \text { Volume } 10, \text { Nomor 6, Desember } 2014 \\ \text { I N D O N E IA } & \text { Halaman } 181-187 \\ \text { ISSN: } 0215-7950 & \text { DOI: } 10.14692 / \text { jfi. } 10.6 .181\end{array}$

\title{
Infeksi Bean common mosaic virus pada Umur Tanaman Kacang Panjang yang Berbeda
}

\author{
Infection of Bean common mosaic virus on \\ Different Age of Yard Long Bean
}

\author{
Hamdayanty, Tri Asmira Damayanti* \\ Institut Pertanian Bogor, Bogor 16680
}

\begin{abstract}
ABSTRAK
Bean common mosaic virus (BCMV) merupakan salah satu virus penting yang menginfeksi kacang panjang karena menyebabkan produksi menurun dan bersifat tular benih. Penelitian bertujuan menentukan terjadinya infeksi BCMV pada umur tanaman berbeda terhadap efisiensi BCMV terbawa benih serta pengaruhnya pada pertumbuhan vegetatif dan produksi kacang panjang. Inokulasi BCMV dilakukan secara mekanis pada tanaman berumur 1, 2, 3, dan 4 minggu setelah tanam (MST). Pengamatan dilakukan terhadap periode inkubasi, insidensi dan keparahan penyakit, persentase BCMV terbawa benih, tinggi tanaman, dan produksi polong. Virus dideteksi dengan metode indirect ELISA. Hasil penelitian menunjukkan bahwa semakin muda tanaman terinfeksi BCMV, periode inkubasi semakin cepat, gejala penyakit semakin parah, pertumbuhan tanaman semakin terhambat, dan produksi polong semakin menurun. Keparahan penyakit pada tanaman yang diinokulasi pada umur 1, 2, 3, dan 4 MST berturut-turut 94.6, 83.8, 81.1, dan 69.6\%. Infeksi BCMV pada umur tanaman yang berbeda tidak berpengaruh terhadap insidensi penyakit dan titer virus. Persentase BCMV terbawa benih berturut-turut sebesar 7, 66, 39, dan 24\% pada umur tanaman 1, 2, 3, dan 4 MST. Infeksi BCMV pada tanaman umur 2 MST merupakan masa kritis tanaman menghasilkan benih yang membawa BCMV.
\end{abstract}

Kata kunci: BCMV, Potyvirus, tular benih, umur tanaman

\begin{abstract}
Bean common mosaic virus (BCMV) is one of the most important virus infecting yard long bean because it can decrease yield and seed transmitted. The aims of research were to determine the effect of plant age infected by BCMV on seed transmission efficiency of the virus, as well as its effect on plant growth. BCMV was mechanically inoculated on yard long bean at 1,2, 3, and 4 weeks after planting (WAP). Observation was conducted for incubation period, disease incidence and severity, seed transmission efficiency of the virus, plant height, and productivity of the plants. Virus infection was detected using indirect ELISA method. The results showed that the earlier infection of BCMV occurred the shortest incubation period, the most severe symptoms, the highest inhibition of plant growth, and productivity. Disease severity was $94.6,83.8,81.1$, and $69.6 \%$ on plants inoculated at $1,2,3$, and 4 WAP, respectively. Disease incidence and virus titer was not affected by infection on different plant age. Seed transmission of BCMV was 7, 66, 39, and $24 \%$ on plants inoculated at 1, 2, 3, and 4 WAP, respectively. Infection on 2 WAP was considered the critical times for BCMV to be seed-borne on yard long bean.
\end{abstract}

Key words: BCMV, plant age, Potyvirus, seed transmitted

*Alamat penulis korespondensi: Departemen Proteksi Tanaman, Fakultas Pertanian, Institut Pertanian Bogor, Jalan Kamper Kampus Darmaga, Bogor 16680.

Tel: 0251-8629364, Faks: 0251-862362, Surel: triadys@yahoo.com 


\section{PENDAHULUAN}

Bean common mosaic virus (BCMV) merupakan salah satu penyebab mosaik pada kacang panjang dan termasuk virus penting yang dapat menyebabkan penurunan produksi (Zheng et al. 2002). Infeksi BCMV menjadi salah satu penyebab penyakit mosaik kuning di Jawa Barat dan Jawa Tengah dengan insidensi penyakit mencapai 100\% (Damayanti et al. 2009). Penyebab penting tersebarnya penyakit ini ialah sifat BCMV yang merupakan patogen tertular benih (Udayashankar et al. 2010).

Gejala infeksi BCMV pada tanaman kacang panjang berupa daun berwarna kuning terang, penebalan pada tulang daun, dan permukaan daun tidak rata akibat pertumbuhan urat daun tidak sebanding dengan pertumbuhan helaian daun (Zheng et al. 2002). Gejala infeksi BCMV yang lain berupa mosaik berupa lepuhan, pola warna kuning dan hijau pada daun, malformasi daun, daun menggulung, tanaman menjadi kerdil, dan polong serta biji yang dihasilkan lebih sedikit dibandingkan dengan tanaman sehat (Morales dan Castano 1987; Flores-Estévez et al. 2003; Udayashankar et al. 2010).

Tanaman yang terinfeksi virus pada umur tanaman yang berbeda akan menunjukkan respons yang berbeda. Semakin muda tanaman diinfeksi virus, insidensi penyakit semakin tinggi, periode inkubasi menjadi lebih singkat, dan distirbusi virus semakin cepat (Akhtar $e t$ al. 2004; Mandal et al. 2007). Belum banyak informasi terkait efisiensi BCMV terbawa benih kacang panjang, sedangkan insidensi penyakit mosaik kacang panjang akibat infeksi BCMV masih tinggi di lapangan. Tingginya insidensi BCMV di lapangan diduga disebabkan oleh tingginya BCMV terbawa benih. Oleh karena itu penelitian bertujuan menentukan pengaruh infeksi BCMV pada umur tanaman berbeda terhadap efisiensi BCMV terbawa benih serta pengaruhnya pada pertumbuhan vegetatif dan produksi kacang panjang.

\section{BAHAN DAN METODE}

\section{Perbanyakan Inokulum}

Inokulum BCMV asal Cirebon diperbanyak secara mekanis pada tanaman kacang panjang kultivar Parade umur 7 hari setelah tanam (HST). Cairan perasan dibuat dengan cara menggerus daun terinfeksi BCMV dalam bufer fosfat $0.01 \mathrm{M} \mathrm{pH} 7.0$ yang mengandung merkaptoetanol $1 \%$ dengan perbandingan 1:5 (b/v). Permukaan daun yang akan diinokulasi virus sebelumnya ditabur dengan karborundum 600 mesh. Cairan perasan kemudian dioleskan pada permukaan atas daun. Karborundum yang masih menempel pada daun dibersihkan dengan air mengalir.

\section{Penanaman dan Pemeliharaan Tanaman Uji}

Benih kacang panjang yang digunakan ialah kultivar Parade. Lahan yang digunakan berupa lahan kering berukuran $100 \mathrm{~m}^{2} \mathrm{di}$ daerah Darmaga, Bogor. Benih ditanam dengan jarak tanam $20 \mathrm{~cm} \times 50 \mathrm{~cm}$ dan diberi pupuk kompos, urea, SP-36, dan $\mathrm{KCl}$ masingmasing dengan dosis 75 ton ha- ${ }^{-1}, 100 \mathrm{~kg} \mathrm{ha}^{-1}$, $100 \mathrm{~kg} \mathrm{ha}^{-1}$, dan $200 \mathrm{~kg} \mathrm{ha}^{-1}$. Pemantauan hama dan penyakit tanaman dilakukan setiap hari khususnya untuk hama Aphis craccivora yang merupakan vektor BCMV. Pengendalian A. craccivora secara mekanis dan kimiawi menggunakan insektisida berbahan aktif imidakloprid 5\% dengan volume cairan semprot $725 \mathrm{~L} \mathrm{ha}^{-1}$. Panen dilakukan sebanyak 3 kali dengan interval panen 1 kali seminggu yang dimulai saat tanaman berumur 8 minggu setelah tanam (MST).

\section{Perlakuan Inokulasi BCMV pada Umur Tanaman yang Berbeda}

Empat perlakuan umur inokulasi tanaman kacang panjang yang diuji ialah 1, 2, 3, 4 MST dan perlakuan tanpa inokulasi virus sebagai kontrol tanaman sehat. Tiap perlakuan terdiri atas 3 petak sebagai ulangan dan masing- 
masing ulangan terdiri atas 20 tanaman. Petak diacak secara kelompok. Inokulasi BCMV dilakukan secara mekanis seperti pada tahap perbanyakan inokulum.

\section{Peubah Pengamatan}

Pengamatan yang dilakukan meliputi tinggi tanaman, periode inkubasi, tipe gejala, insidensi dan keparahan penyakit, titer BCMV, persentase BCMV terbawa benih, dan bobot polong. Pengukuran tinggi tanaman dilakukan 2 minggu sekali hingga 6 MST. Insidensi penyakit (IP) dihitung menggunakan rumus:

$\mathrm{IP}=\frac{\text { Jumlah tanaman terinfeksi }}{\text { Jumlah tanaman yang diinokulasi }} \times 100 \%$

Keparahan penyakit dihitung setiap minggu dengan mengukur skor penyakit pada masing-masing tanaman uji. Kategori skor yang digunakan ialah 0 , tidak bergejala; 1 , gejala mosaik ringan; 2 , gejala mosaik sedang; 3 , gejala mosaik berat; 4 , gejala mosaik berat dengan malformasi daun yang parah, kerdil, atau mati (Gambar 1). Nilai skor yang diukur kemudian dikonversi dalam nilai keparahan penyakit (KP) menggunakan rumus:

$$
\mathrm{KP}=\frac{\sum\left(\mathrm{n}_{\mathrm{i}} \times \mathrm{v}_{\mathrm{i}}\right)}{\mathrm{N} \times \mathrm{V}} \times 100 \% \text {, dengan }
$$

$\mathrm{n}_{\mathrm{i}}$, jumlah tanaman dengan skor ke-i; $\mathrm{v}_{\mathrm{i}}$, nilai skor penyakit; $N$, jumlah tanaman yang diamati; $\mathrm{V}$, skor tertinggi.

\section{Deteksi BCMV dari Tanaman dan Benih}

Sampel daun dari tanaman hasil inokulasi diambil pada 4 minggu setelah inokulasi (MSI) dan dideteksi untuk mengetahui perbedaan titer virus untuk masing-masing perlakuan waktu inokulasi yang berbeda.
Sebanyak 100 benih kacang panjang hasil panen tiap perlakuan inokulasi ditanam dalam baki berisi tanah steril sampai berumur 3 MST. Sampel tanaman dan sampel asal benih yang ditumbuhkan kemudian dideteksi menggunakan antiserum BCMV dengan metode indirect ELISA sesuai dengan protokol yang dibuat oleh produsen antiserum (Agdia).

\section{Rancangan Percobaan dan Analisis Data}

Rancangan percobaan yang digunakan ialah rancangan acak kelompok. Sebagai perlakuan ialah umur tanaman saat diinokulasi pada 1, 2, 3, 4 MST, dan kontrol. Data periode inkubasi, insidensi penyakit dan keparahan penyakit, tinggi tanaman, dan produksi polong kacang panjang dianalisis menggunakan ANOVA program SAS versi 9.0. Perlakuan yang memberikan pengaruh nyata diuji lanjut dengan uji Duncan pada taraf $\alpha 5 \%$.

\section{HASIL}

\section{Periode Inkubasi dan Tipe Gejala BCMV}

Semakin muda tanaman kacang panjang terinfeksi BCMV, periode inkubasi semakin singkat (Tabel 1). Tanaman kacang panjang yang diinokulasi BCMV umur 1 MST memiliki periode inkubasi yang lebih singkat (8-9 HST) dibandingkan dengan perlakuan lain. Periode inkubasi BCMV pada tanaman yang diinokulasi BCMV umur 3 MST tidak berbeda nyata dengan tanaman yang diinokulasi BCMV umur 2 dan 4 MST.

Tipe gejala infeksi BCMV berbeda berdasarkan waktu inokulasi (Tabel 1). Semakin cepat tanaman terinfeksi BCMV maka gejala yang muncul juga semakin parah.

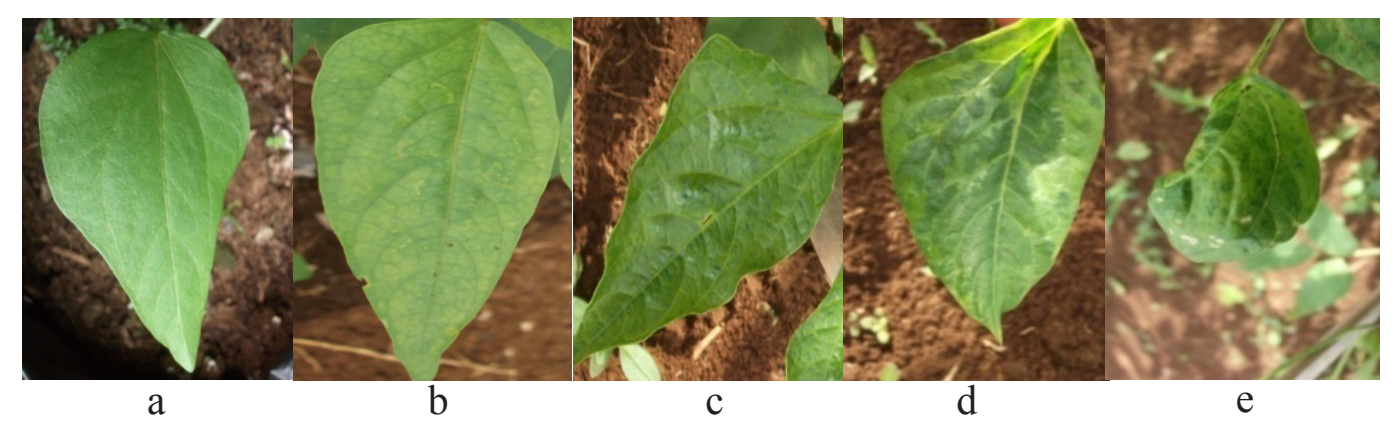

Gambar 1 Skor keparahan penyakit berdasarkan gejala. a, skor 0; b, skor 1; c, skor 2; d, skor 3 ; dan e, skor 4. 
Tabel 1 Periode inkubasi dan tipe gejala infeksi BCMV pada tanaman kacang panjang yang diinokulasi pada umur tanaman yang berbeda

\begin{tabular}{lcc}
\hline $\begin{array}{c}\text { Umur tanaman saat diinokulasi } \\
(\text { MST) }\end{array}$ & $\begin{array}{c}\text { Periode inkubasi* } \\
(\text { HSI })\end{array}$ & Tipe gejala** \\
\hline 1 & $8.22 \pm 0.20 \mathrm{c}$ & MsR, MsB, MF, Kng, Kd \\
2 & $13.75 \pm 2.08 \mathrm{~b}$ & MsR, MsB, MF, Kng \\
3 & $15.12 \pm 3.42 \mathrm{ab}$ & MsR, MsB \\
4 & $17.38 \pm 2.33 \mathrm{a}$ & MsR, MsB \\
Kontrol & - & Tidak ada gejala \\
\hline
\end{tabular}

*HSI: hari setelah inokulasi.

**MsR, mosaik ringan; MsB, mosaik berat; MF, malformasi; Kng, kuning; Kd, Kerdil.

MST, minggu setelah tanam.

Gejala khas BCMV berupa penebalan tulang daun yang tampak pada tipe gejala mosaik berat. Beberapa tanaman juga menunjukkan adanya daun menguning pada saat tanaman memasuki fase pembungaan. Tanaman dengan gejala daun menguning juga menghasilkan polong dengan gejala mosaik dan malformasi polong (Gambar 2).

\section{Insidensi dan Keparahan Penyakit serta Titer BCMV}

Inokulasi BCMV pada tanaman umur 1-4 MST menunjukkan insidensi penyakit sebesar 100\% (Tabel 2). Hal ini menunjukkan bahwa inokulasi BCMV pada umur tanaman kacang panjang yang berbeda tidak memberikan pengaruh terhadap tingkat insidensi penyakit BCMV di lapangan. Semakin muda tanaman diinokulasi BCMV menunjukkan keparahan penyakit tanaman semakin meningkat (Tabel 2). Keparahan penyakit tertinggi sampai terendah sesuai dengan umur tanaman saat diinokulasi.

Nilai absorbansi ELISA(NAE) merupakan gambaran kuantitatif virus yang menginfeksi tanaman. NAE dari setiap perlakuan $(1,2,3$, dan 4 MST) menunjukkan hasil yang tidak berbeda nyata (Tabel 2).

\section{BCMV Terbawa Benih}

Persentase BCMV terbawa benih yang dipanen dari tanaman perlakuan menunjukkan bahwa dari masing-masing 100 benih yang diuji, BCMV terbawa benih sebesar 7, 66, 39 , dan $24 \%$ berturut-turut untuk perlakuan inokulasi umur 1, 2, 3, dan 4 MST.

\section{Pengaruh Infeksi BCMV terhadap Tinggi Tanaman dan Produksi Kacang Panjang}

Inokulasi BCMV menghambat pertumbuhan tanaman dan mengurangi produksi polong kacang panjang. Secara umum, semakin muda tanaman terinfeksi BCMV semakin terhambat tinggi tanaman. Efek infeksi BCMV terhadap tinggi tanaman telah terlihat pada saat tanaman berumur 4 MST khususnya pada tanaman yang diinokulasi BCMV umur 1 MST (Gambar 3). Semakin muda tanaman saat terinfeksi BCMV, produksi polong per ha juga semakin menurun. Penurunan produksi yang nyata terjadi saat tanaman kacang panjang terinfeksi BCMV pada umur $1 \mathrm{MST}$, yaitu sebesar $44.9 \%$ (Tabel 3).

\section{PEMBAHASAN}

Periode inkubasi erat kaitannya dengan kemampuan virus menyebar dari tempat inokulasi ke bagian tanaman lainnya dan kemudian menunjukkan gejala. Virus mampu menyebar ke bagian tanaman yang masih muda dengan cepat karena tanaman muda belum memiliki sistem pertahanan yang kuat terhadap infeksi virus (Garcia-Ruiz dan Purphy 2001). Hal ini dapat menyebabkan semakin muda tanaman kacang panjang terinfeksi BCMV, periode inkubasi virus semakin cepat.

Gejala akibat infeksi BCMV yang paling parah adalah gejala mosaik dan vein banding. Munculnya gejala mosaik disebabkan adanya area yang terinfeksi dan tidak terinfeksi virus. Area yang terinfeksi virus biasanya berwarna hijau pucat karena hilangnya atau 


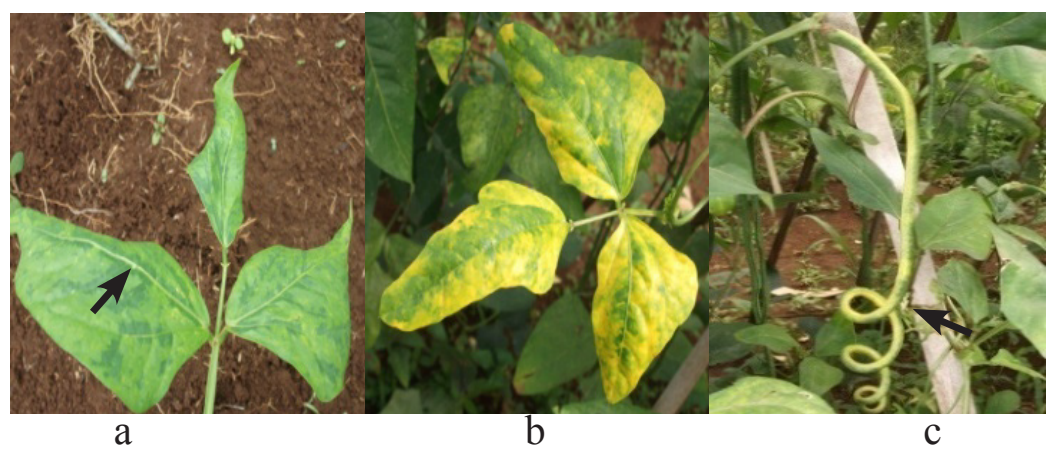

Gambar 2 Gejala BCMV pada tanaman kacang panjang. a, penebalan tulang daun; $b$, daun menguning; c, mosaik dan malformasi polong.

Tabel 2 Insidensi penyakit, keparahan penyakit, dan nilai absorbansi ELISA hasil inokulasi BCMV pada umur tanaman kacang panjang yang berbeda

\begin{tabular}{lccc}
$\begin{array}{l}\text { Waktu inokulasi } \\
(\mathrm{MST})\end{array}$ & $\begin{array}{c}\text { Insidensi penyakit* } \\
(\%)\end{array}$ & $\begin{array}{c}\text { Keparahan penyakit* } \\
(\%)\end{array}$ & $\begin{array}{c}\text { nilai absorbansi ELISA } \\
(\mathrm{NAE})\end{array}$ \\
\hline 1 & $100 \pm 0 \mathrm{a}$ & $94.58 \pm 1.91 \mathrm{a}$ & $0.98 \pm 0.01 \mathrm{a}$ \\
2 & $100 \pm 0 \mathrm{a}$ & $83.75 \pm 4.33 \mathrm{~b}$ & $1.00 \pm 0.09 \mathrm{a}$ \\
3 & $100 \pm 0 \mathrm{a}$ & $87.08 \pm 8.04 \mathrm{ab}$ & $1.09 \pm 0.26 \mathrm{a}$ \\
4 & $100 \pm 0 \mathrm{a}$ & $69.58 \pm 6.41 \mathrm{c}$ & $1.01 \pm 0.01 \mathrm{a}$ \\
Kontrol & $0 \pm 0 \mathrm{~b}$ & $0.00 \pm 0.00 \mathrm{~d}$ & $0.11 \pm 0.03 \mathrm{~b}$ \\
\hline *Angka yang diikuti huruf yang sama pada kolom yang sama tidak berbeda nyata pada uji Duncan pada taraf $\alpha 5 \%$
\end{tabular}

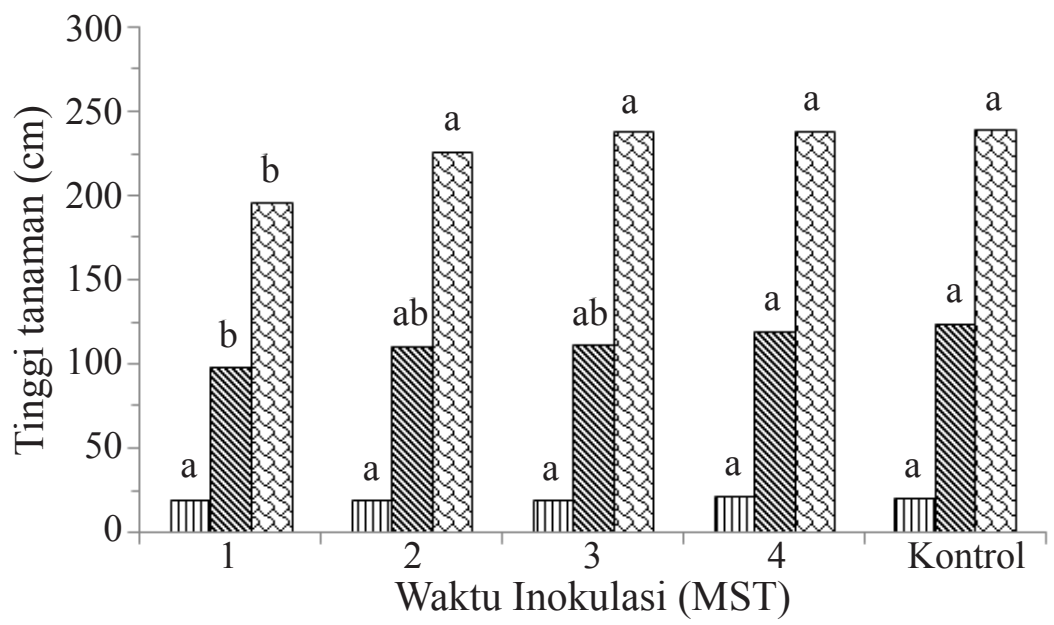

Gambar 3 Tinggi tanaman kacang panjang pada perlakuan waktu inokulasi BCMV yang berbeda. $\mathbb{U}$, tinggi tanaman 2 minggu setelah tanam (MST); $\mathbf{N}$, tinggi tanaman 4 MST; 囚, tinggi tanaman 6 MST. Notasi huruf yang sama menunjukkan tinggi tanaman yang tidak berbeda nyata pada uji Duncan pada taraf kepercayaan 5\%.

Tabel 3 Produksi kacang panjang yang diberi perlakuan inokulasi BCMV pada umur tanaman yang berbeda

\begin{tabular}{lcc}
\hline $\begin{array}{l}\text { Waktu inokulasi } \\
(\text { minggu setelah tanam) }\end{array}$ & $\begin{array}{c}\text { Produksi* } \\
\left(\text { ton } \mathrm{ha}^{-1}\right)\end{array}$ & $\begin{array}{c}\text { Penurunan produksi } \\
(\%)\end{array}$ \\
\hline 1 & $5.49 \pm 0.32 \mathrm{~b}$ & 44.9 \\
2 & $8.15 \pm 1.63 \mathrm{a}$ & 18.2 \\
3 & $8.84 \pm 1.54 \mathrm{a}$ & 11.3 \\
4 & $9.39 \pm 1.68 \mathrm{a}$ & 5.7 \\
Kontrol & $9.96 \pm 0.85 \mathrm{a}$ & 0 \\
\hline
\end{tabular}

*Angka yang diikuti huruf yang sama pada kolom yang sama tidak berbeda nyata pada uji Duncan pada taraf $\alpha$ 5\% 
berkurangnya produksi klorofil. Persentase penurunan kandungan klorofil a, klorofil b, karotenoid, karbohidrat, protein, dan asam amino akibat infeksi Bean yellow mosaic potyvirus (BYMV) pada Phaseolus vulgaris semakin meningkat seiring dengan meningkatnya umur tanaman (Hemida 2005). Infeksi BCMV pada umur tanaman yang lebih muda dapat menyebabkan penurunan klorofil tanaman lebih awal dibandingkan dengan tanaman yang diinokulasi pada tanaman yang lebih tua. Pengurangan klorofil yang lebih awal dapat menyebabkan gejala mosaik yang muncul pada tanaman lebih parah sehingga meningkatkan keparahan penyakit pada tanaman. Keparahan yang lebih tinggi pada tanaman muda disebabkan karena tanaman belum memiliki ketahanan yang kuat terhadap infeksi virus (Wintermantel dan Kaffka 2006). Oleh karena itu semakin cepat tanaman terinfeksi maka keparahan penyakit juga semakin tinggi.

Tanaman buncis kultivar Dubbele Witte yang diinfeksi BCMV pada umur 10, 20, dan 30 HST menyebabkan BCMV terbawa benih berturut-turut sebesar 41.8, 2.8, dan $0.1 \%$ (Morales dan Castano 1987). Pada kasus BCMV yang menginfeksi kacang panjang dalam penelitian ini, persentase BCMV terbawa benih tertinggi pada tanaman yang diinokulasi BCMV umur 2 MST, bukan pada umur 1 MST, kemudian menurun hingga 4 MST. Hal ini menunjukkan bahwa infeksi virus yang sama pada tanaman yang berbeda menyebabkan perbedaan masa rentan tanaman terinfeksi virus dan efisiensi terbawa benih.

Rendahnya BCMV terbawa benih pada tanaman yang diinokulasi 1 MST dibandingkan dengan 2 MST dapat disebabkan oleh pertumbuhan yang sangat terhambat pada tanaman yang diinokulasi umur 1 MST hingga menyebabkan penghambatan pembentukan polong dan benih kacang panjang. Pembentukan benih yang terhambat menandakan proses pengangkutan nutrisi tanaman ke benih terhambat yang berarti pengangkutan virus ke benih juga terhambat. Persentase BCMV terbawa benih yang tinggi pada tanaman yang diinokulasi umur 2 MST menunjukkan kemampuan virus terbawa pada benih yang sangat tinggi.

Benih kacang tunggak yang terinfeksi BCMV sebesar 10, 5, dan 3\% dapat menyebabkan insidensi penyakit pada pertanaman selanjutnya sebesar 90,53 , dan $37 \%$ serta kehilangan hasil sebesar 74, 54, dan 36\% (Udayashankar et al. 2010). Berdasarkan keparahan penyakit dan kehilangan hasil akibat BCMV terbawa benih ini diketahui bahwa BCMV terbawa benih memiliki peran yang sangat penting terhadap kehilangan hasil walaupun dalam persentase terbawa benih yang kecil. Tingginya persentase BCMV terbawa benih pada penelitian ini dapat menggambarkan tingginya keparahan penyakit yang akan timbul jika benih-benih tersebut ditanam.

Semakin cepat tanaman terinfeksi BCMV maka pertumbuhan tanaman semakin terhambat. Efek penghambatan tinggi tanaman terlihat ketika tanaman diinokulasi BCMV pada umur 1 MST. Pada umur 1 MST diduga tanaman belum mempunyai sistem pertahanan yang cukup kuat untuk menghambat replikasi virus sehingga kemampuan virus untuk menghambat pertumbuhan tanaman juga semakin tinggi. Kacang panjang dari tanaman yang diinfeksi BCMV umur 1 MST menunjukkan penurunan produksi yang sangat tinggi. Tanaman yang terinfeksi virus dapat menjadi kerdil dan menghasilkan sedikit polong, masak lebih lambat dibandingkan dengan polong yang tidak terinfeksi. Infeksi virus pada tanaman yang muda akan mengakibatkan kerugian hasil yang lebih tinggi dibandingkan dengan apabila infeksi terjadi pada tanaman yang lebih tua (Udayashankar et al. 2010).

Infeksi BCMV pada umur tanaman yang berbeda berpengaruh pada periode inkubasi, keparahan penyakit, pertumbuhan tanaman, produksi, dan persentase BCMV terbawa benih. Secara umum, semakin muda tanaman terinfeksi BCMV akan menyebabkan periode inkubasi virus lebih singkat, keparahan penyakit lebih tinggi, dan pertumbuhan terhambat serta produksi lebih rendah dibandingkan dengan kontrol 
atau infeksi BCMV pada umur tanaman yang lebih tua. Infeksi BCMV pada umur tanaman yang berbeda tidak berpengaruh nyata pada insidensi penyakit dan titer virus. Di antara umur tanaman yang berbeda saat terinfeksi BCMV, umur 2 MST merupakan masa kritis tanaman terhadap infeksi BCMV terbawa benih kacang panjang dibandingkan dengan inokulasi BCMV umur 1, 3, dan 4 MST.

\section{DAFTAR PUSTAKA}

Akhtar AP, Hussain M, Khan AI, Haq MA, Iqbal MM. 2004. Influence of plant age, whitefly population and cultivar resistance on infection of cotton plants by Cotton leaf curl virus $(\mathrm{CLCuV})$ in Pakistan. Field Crops Res. 86(1):15-21. DOI: http://dx.doi.org/10.1016/S0378-42900(03)00166-7.

Damayanti TA, Alabi OJ, Naidu RA, Rauf N. 2009. Severe outbreak of a yellow mosaic disease on the yard long bean in Bogor, West Java. Hayati J Biosci. 16(2):7882. DOI: http://dx.doi.org/10.4308/ hjb.16.2.78.

Flores-Estévez N, Acosta-Gallegos JA, SilvaRosales L. 2003. Bean common mosaic virus and Bean common mosaic necrosis virus in Mexico. Plant Dis. 87(1):21-25. DOI: http://dx.doi.org/10.1094/ PDIS.2003.87.1.21.

Garcia-Ruiz H, Purphy JH. 2001. Agerelated resistance in bell pepper to Cucumber mosaic virus. Ann Appl Biol. 139(3):307-317. DOI: http://dx.doi. org/10.1111/j.1744-7348.2001.tb00144.x.
Hemida SK. 2005. Effect of Bean yellow mosaic virus on physiological parameters of Vicia faba and Phaseolus vulgaris. Int $\mathbf{J}$ Agric Biol. 7(2):154-157.

Mandal B, Wells ML, Martinez-Ochoa N, Csinos AS, Pappu HR. 2007. Symptom development and distribution of Tomato spotted wilt virus in flue-cured tobacco. Ann Appl Biol. 151(1):67-75. DOI: http://dx.doi.org/10.1111/j.17447348.2007.00153.x.

Morales FJ, Castano M. 1987. Seed transmission characteristics of selected BCMV strains in differential cultivars. Plant Dis. 71(1):51-53. DOI: http://dx.doi. org/10.1094/PD-71-0051.

Udayashankar AC, Nayaka SC, Kumar HB, Mortensen CN, Shetty HS, Prakash HS. 2010. Establishing inoculum threshold levels for Bean common mosaic virus strain Blackeye cowpea mosaic infection in cowpea seed. Afr J Biotech. 9(53):89588969. DOI: http://dx.doi.org/10.5897/ AJB09.1066.

Wintermantel WM, Kaffka SR. 2006. Sugar beet performance with curly top is related to virus accumulation and age at infection. Plant Dis. 90(5):657-662. DOI: http:// dx.doi.org/10.1094/PD-90-0657.

Zheng H, Chen J, Chen J, Adams MJ, Hou M. 2002. Bean common mosaic virus isolates causing different symptoms in asparagus bean in China differ greatly in the $5^{\circ}$ parts of their genomes. Arch Virol. 147:12571262. DOI: http://dx.doi.org/10.1007/ s00705-002-0805-7. 